\title{
Seasonal lipid storage and dietary preferences of native European versus invasive Asian shore crabs
}

\author{
Simon Jungblut ${ }^{1,2, *}$, Morgan L. McCarthy $y^{1,2,3}$, Karin Boos ${ }^{1,4}$, \\ Reinhard Saborowski ${ }^{2}$, Wilhelm Hagen ${ }^{1}$
}

\author{
${ }^{1}$ Bremen Marine Ecology (BreMarE), Marine Zoology, University of Bremen, 28359 Bremen, Germany \\ ${ }^{2}$ Alfred Wegener Institute, Helmholtz Centre for Polar and Marine Research, 27570 Bremerhaven, Germany \\ ${ }^{3}$ Department of Earth and Planetary Sciences, Johns Hopkins University, Baltimore, MD 21218, USA \\ ${ }^{4}$ MARUM - Center for Marine Environmental Sciences, University of Bremen, 28359 Bremen, Germany
}

\begin{abstract}
The invasive Asian shore crab Hemigrapsus sanguineus and the native European green crab Carcinus maenas share intertidal habitats along European North Atlantic shores and may compete for food. We evaluated the energy-storing capacities of the 2 species and determined their dietary preferences by means of lipid analysis and fatty acid trophic marker indices. Specimens of both sexes and various sizes were sampled in the rocky intertidal of the island of Helgoland (North Sea) in April, June, August, and October 2015. Total lipids of the midgut glands were significantly higher in $H$. sanguineus than in C. maenas and followed a distinct seasonal cycle in both sexes (ca. 20-50\% of dry mass, DM). The lower lipid contents of C. maenas (ca. $20 \%$ of DM) remained at a similar level throughout the seasons. The seasonal differences in the females of $H$. sanguineus may be due to higher reproductive output and, consequently, lipid turnover, but remain unexplained in males. Trophic indices for Bacillariophyceae, Chlorophyta, and especially Phaeophyceae were higher in $H$. sanguineus than in C. maenas, suggesting a higher degree of herbivory of the invader. In contrast, the Rhodophyta index was higher in C. maenas. Thus, competition for food between the 2 species will probably be low in habitats rich in macroalgae. The ability of $H$. sanguineus to utilize mainly energy-poor algae but accumulate high-energy reserves may be an advantage for successfully establishing persistent populations in new habitats.
\end{abstract}

KEY WORDS: Asian shore crab $\cdot$ Hemigrapsus sanguineus $\cdot$ European green crab $\cdot$ Carcinus maenas $\cdot$ Competition $\cdot$ Trophic markers $\cdot$ Fatty acids $\cdot$ North Sea

\section{INTRODUCTION}

Biological invasions can entail severe ecological changes (Vitousek et al. 1997, Grosholz 2002, Didham et al. 2005). Non-indigenous species may alter structures of native communities and negatively influence biodiversity and ecosystem functioning. Ultimately, native species may become extinct, and ecosystem services, economic interests, and human health might be at risk (Ruiz et al. 2000, Gurevitch \& Padilla 2004, Simberloff et al. 2013).
Brachyuran crabs are common invaders of marine and coastal ecosystems (Brockerhoff \& McLay 2011). Among them, the European green crab Carcinus maenas (Linnaeus 1758) and the Asian shore crab Hemigrapsus sanguineus (de Haan 1835) show a very pronounced invasion potential. C. maenas is native to the European and northern African Atlantic coasts and invasive to many other coasts worldwide (Carlton \& Cohen 2003). H. sanguineus originally inhabited the coastlines of Japan, Korea, and China (Fukui 1988, Stephenson et al. 2009) and was de- 
tected along the US east coast in the late 1980s (Williams \& McDermott 1990, Delaney et al. 2008, Epifanio 2013) as well as the European Atlantic coasts from the late 1990s onwards (Breton et al. 2002, Obert et al. 2007, Landschoff et al. 2013, Jungblut et al. 2017). Hence, C. maenas and H. sanguineus share intertidal habitats in their native and invaded habitats in Europe, the US east coast, and Asia, providing an interesting target for species invasion studies.

The factors determining the success of an invader in a new habitat are pivotal topics of ecological research (e.g. Elton 1958, Ruiz et al. 2000, Kolar \& Lodge 2001, Sakai et al. 2001). Most studies are based on population structure and dynamics (e.g. Sakai et al. 2001, Russell et al. 2008, O'Connor 2014). Several ecological models and hypotheses have been established to explain invasive processes, such as the enemy release hypothesis, biotic resistance theory, or community ecology theory (e.g. Lodge 1993, Shea \& Chesson 2002, Colautti et al. 2004). Only a few studies have addressed the underlying physiological mechanisms and properties, which are fundamental drivers of the invader's success (e.g. Kelley 2014).

Feeding and nutritional quality are key factors in heterotrophic organisms (Saborowski 2015). The ability to store energy reserves provides an advantage to overcome periods of food scarcity or starvation during ecdysis. In crabs, the midgut gland (hepatopancreas) is the main storage organ of dietary components such as proteins, carbohydrates, and particularly lipids (Jimenez \& Kinsey 2015). Size and lipid content of the midgut gland provide a suitable indicator for the overall condition of the animal, its storage capacity, and the seasonal dynamics of energy deposition (Kyomo 1988, Griffen et al. 2015, Jimenez \& Kinsey 2015). Moreover, the nutritional state is closely related to reproductive processes (Griffen et al. 2011, 2012, Zeng et al. 2014). Given the success of $H$. sanguineus in invading new areas, we expect this species to store larger amounts of lipids in their midgut glands to buffer periods of low food availability. Moreover, they have been described as 'income breeders', i.e. they use ingested energy directly for egg production, which should result in a rather constant lipid level in the midgut glands, unless food supply differs seasonally (Griffen et al. 2012). In contrast, C. maenas have been described as 'capital breeders', i.e. they deposit energy for the production of eggs prior to the reproductive season, which would result in a more seasonal pattern of lipid levels (Griffen et al. 2011).
Gut content analyses of C. maenas and H. sanguineus classified both species as opportunistic omnivores and thus potential competitors, although $H$. sanguineus has a higher preference for macroalgae (e.g. Ropes 1968, Tyrrell \& Harris 1999, Lohrer et al. 2000, Griffen et al. 2012). Such analyses tend to overestimate recently ingested items and to underestimate easily digestible food. These biases can be eliminated by applying the fatty acid trophic marker (FATM) concept. The composition of fatty acids (FAs) integrates trophic preferences over a longer time period of days to weeks, compared to gut content analyses (Graeve et al. 2001, Dalsgaard et al. 2003, Latyshev et al. 2004).

The aims of the present study were to examine the lipid storage properties and determine feeding preferences of C. maenas and H. sanguineus by applying total lipid (TL) and FA analyses. The results were used to test the following hypotheses:

(1) H. sanguineus stores larger amounts of lipids in the hepatopancreas than C. maenas.

(2) The seasonal variation in TL levels is more pronounced in $C$. maenas than in $H$. sanguineus.

(3) The FA composition differs (i) between species and within each species with (ii) sex, and (iii) seasons.

(4) Trophic marker concentrations (i) differ between C. maenas and $H$. sanguineus, and differ for both species with (ii) size, (iii) sex, and (iv) season.

\section{MATERIALS AND METHODS}

\section{Origin of samples}

Males and females of Carcinus maenas and Hemigrapsus sanguineus were sampled in the intertidal at the southwestern tip ('Kringel') of the island of Helgoland (North Sea; 5410' 36.5" N, $7^{\circ} 53^{\prime} 03.3^{\prime \prime} \mathrm{E}$ ). Crabs were collected during low tides in April, June, August, and October 2015. Macroalgae were sampled at the same site in August 2015.

The sampling site is wave-exposed and composed of coarse sand with small to large rocks and boulders, which are covered with small to medium-sized macroalgae (see Table 3 for the prevailing macroalgae species). Further details about the habitats around Helgoland are provided by Bartsch \& Tittley (2004).

Animals with carapace widths (CW) between 10 and $40 \mathrm{~mm}$ were collected, as these sizes are the most frequent in the intertidal of Helgoland (Jungblut et al. 2017). H. sanguineus do not reach sizes over $40 \mathrm{~mm}$ CW. To analyze animals of similar sizes, no $C$. maenas over $40 \mathrm{~mm} \mathrm{CW}$ were collected. 
C. maenas change their carapace color during the molt cycle from greenish to reddish, accompanied by alterations in behavior and physiology (reviewed by Styrishave et al. 2004). This red color morph was not considered, as it is rare in the intertidal of Helgoland and mostly occurs in subtidal areas. Only crabs with hard carapaces and without eggs were considered for further analysis. Freshly molted (soft carapace) and ovigerous crabs were omitted, as they usually show physiological modifications (e.g. Lewis \& Haefner 1976, Naylor et al. 1997).

After sampling, crabs and algae were immediately transported to the laboratories of the Marine Station on Helgoland. Crabs were maintained in aquaria with aeration at room temperature until further processing on the same day. The $\mathrm{CW}$ of each crab was measured to the nearest $0.5 \mathrm{~mm}$ with Vernier calipers. After blotting dry with paper towels for $10 \mathrm{~s}$, the fresh mass of the crabs was determined to the nearest $0.001 \mathrm{~g}$. The midgut glands of the crabs were dissected and transferred into pre-weighed glass vials. The wet masses of the midgut glands were determined and the vials immediately frozen at $-80^{\circ} \mathrm{C}$. The hepatosomatic index (HSI) was calculated as the wet mass of the fresh midgut gland in relation to the rest of the crab's fresh mass (Kennish 1997, Griffen et al. 2011, 2012; our Table 1). The algae were briefly rinsed in distilled water, blotted dry, and frozen at $-80^{\circ} \mathrm{C}$.

\section{TL extraction and FA analysis}

Samples were transported on dry ice to the laboratories of the University of Bremen, Germany. The samples were lyophilized for $48 \mathrm{~h}$ and their dry mass was determined to the nearest $0.001 \mathrm{~g}$. Lipids were extracted with dichloromethane:methanol (2:1 per volume) and an aqueous solution of $\mathrm{KCl}(0.88 \%)$ after
Folch et al. (1957) and Hagen (2000). TL content was determined gravimetrically to the nearest $0.001 \mathrm{~g}$ and calculated as the percentage of lipids in relation to the dry mass of the sample (\% $\%_{D M}$; Table 1 ). For the analysis of FAs, subsamples of the lipid extracts were treated with methanol containing $3 \%$ concentrated sulfuric acid to convert them to methyl ester derivatives (FAMEs), which can be quantified by gas chromatography (GC; Kattner \& Fricke 1986). The GC device (Agilent Technologies, 7890A) was equipped with a DB-FFAP column (30 m length, $0.25 \mathrm{~mm}$ diameter) and run with helium as carrier gas. It was operated with a programmable temperature vaporizer injector. The FAs were identified by their retention times. Menhaden fish oil and lipids of the copepod Calanus hyperboreus Krøyer, 1838 were used as standards (Schukat et al. 2014, Bode et al. 2015).

Free fatty alcohols and unidentified components accounted for only about $1 \%$ of the total sample each and were not further considered. The FA dataset was evaluated according to the FATM concept. This concept is well established for marine zooplankton (reviewed by Dalsgaard et al. 2003, Lee et al. 2006) and has also been applied to benthic systems (reviewed by Kelly \& Scheibling 2012). We developed new dietary indices to better distinguish between food items, i.e. carnivorous diet $\left(\mathrm{I}_{\mathrm{Ca}}\right)$, Chlorophyta $\left(\mathrm{I}_{\mathrm{Ch}}\right)$, Phaeophyceae $\left(\mathrm{I}_{\mathrm{P}}\right)$, Rhodophyta $\left(\mathrm{I}_{\mathrm{R}}\right)$, and Bacillariophyceae $\left(\mathrm{I}_{\mathrm{B}}\right)$ (Table 1$)$.

The FAs 18:1(n-7), 18:2(n-6), 18:3(n-3), and 18:4(n-3) are major components of Chlorophyta (green macroalgae). Additionally, 16:4(n-3) is a dominating FA in the order Ulvales (Kelly \& Scheibling 2012 and references therein). Because 18:4(n-3) is the only FA that could be used as an indicator for Phaeophyceae (brown macroalgae) (Kelly \& Scheibling 2012), it was omitted as a green algae indicator. Thus, $\mathrm{I}_{\mathrm{Ch}}=$ $16: 4(n-3)+18: 1(n-7)+18: 2(n-6)+18: 3(n-3)$ was used

Table 1. Equations for the calculation of condition parameters and fatty acid-based trophic marker indices

\begin{tabular}{|c|c|}
\hline Parameter & Equation \\
\hline Hepatosomatic index & 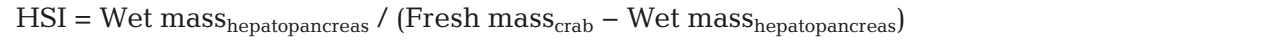 \\
\hline Total lipid content ( $\left.\%_{\mathrm{DM}}\right)$ & $\mathrm{TL}=$ MasS $_{\text {extracted lipids }} /$ Dry $_{\text {mass }}$ sample $\times 100$ \\
\hline Carnivory index & $\begin{aligned} \mathrm{I}_{\mathrm{Ca}}= & 18: 1(\mathrm{n}-9) /[16: 1(\mathrm{n}-7)+16: 4(\mathrm{n}-3)+16: 4(\mathrm{n}-1)+18: 1(\mathrm{n}-7)+18: 2(\mathrm{n}-6)+18: 3(\mathrm{n}-3)+18: 4(\mathrm{n}-3) \\
& +20: 4(\mathrm{n}-6)+20: 5(\mathrm{n}-3)]\end{aligned}$ \\
\hline Chlorophyta index & $I_{C h}=16: 4(n-3)+18: 1(n-7)+18: 2(n-6)+18: 3(n-3)$ \\
\hline Phaeophyceae index & $I_{P}=18: 4(n-3)$ \\
\hline Rhodophyta index & $I_{R}=20: 5(n-3) /[16: 0+18: 0+22: 6(n-3)]$ \\
\hline Bacillariophyceae index & $\mathrm{I}_{\mathrm{B}}=16: 1(\mathrm{n}-7)+16: 4(\mathrm{n}-1)$ \\
\hline
\end{tabular}


as the dietary index for Chlorophyta, and $I_{P}=18: 4$ (n3 ) as the indicator for Phaeophyceae. Rhodophyta (red macroalgae) are particularly rich in 20:5(n-3), which is also an important biomembrane FA in marine animals (Kelly \& Scheibling 2012). The red algae diet index $I_{R}=20: 5(n-3) /[16: 0+18: 0+22: 6(n-3)]$ sets 20:5(n-3) in relation to the 3 other FAs generally known as membrane FAs (Lee et al. 2006, Boissonnot et al. 2016). A high index might, thus, indicate consumption of red algae. The sum of $I_{B}=16: 1(n-7)+$ 16:4(n-1) was used as an index for diatom ingestion. 18:1(n-7) is also a Bacillariophyceae marker (Dalsgaard et al. 2003). However, the latter is also abundant in green algae and was thus omitted in the diatom index (Kelly \& Scheibling 2012). The FA $18: 4(\mathrm{n}-3)$ is commonly used as dinoflagellate marker (Dalsgaard et al. 2003). It is also prevalent in green and brown algae (Kelly \& Scheibling 2012) and thus cannot contribute to a dinoflagellate index. However, crabs probably do not distinguish between diatoms and dinoflagellates, and a high diatom index might thus generally indicate ingestion of benthic microalgae. To assess the carnivory of the crabs, we developed a carnivory index similar to that of zooplankton (Schukat et al. 2014, Bode et al. 2015). The carnivory marker FA 18:1(n-9) was used versus all FAs that are abundant or are marker FAs for algae: $\mathrm{I}_{\mathrm{Ca}}=$ $18: 1(\mathrm{n}-9) /[16: 1(\mathrm{n}-7)+16: 4(\mathrm{n}-3)+16: 4(\mathrm{n}-1)+18: 1(\mathrm{n}-7)$ $+18: 2(\mathrm{n}-6)+18: 3(\mathrm{n}-3)+18: 4(\mathrm{n}-3)+20: 4(\mathrm{n}-6)+$ 20:5(n-3)]. For benthic animals, $\mathrm{I}_{\mathrm{Ca}}$ has to be interpreted with caution, as 18:1(n-9) is also an abundant FA in Phaeophyceae. This has to be considered when evaluating high $\mathrm{I}_{\mathrm{Ca}}$ levels to avoid misinterpretations.

\section{Statistical analysis}

We used R version 3.2.3 (R Development Core Team 2015) to develop 7 individual linear models to test for the effects of the fully crossed factors 'species', 'sex', 'month', and 'fresh mass' on HSI, TL, and the 5 trophic marker indices. If needed, data were $\log ($ data +1$)$-transformed to meet the assumptions of normal distribution and homogeneous variances of the residuals. Model stability was checked using Cook's distance, leverage, and dffits. All models were fitted using the generic function ' $1 \mathrm{~m}$ '. Significances of main factors and interaction terms were established with likelihood ratio tests (LRTs) using the function 'anova' with the argument 'test' set to ' $F$ '. Non-significant terms/factors were excluded, unless they were relevant for significant interactions of higher orders. Graphs were produced with the software GraphPad Prism (version 5.03).

Principal component analyses (PCAs) were conducted using the whole set of FA components (see Table 3). The percentages of each sample were transformed to proportions and arcsine-square-root transformed to achieve normality and homogeneity of variances. First, samples were checked for clustering by sex within one species and season. Subsequently, each species was checked for seasonal differences, not considering sexes any more. Finally, a PCA was conducted using all samples, including the algae. PCAs were conducted and graphs were produced with Primer v6 software (Clarke \& Warwick 1994).

For more details, see 'Statistical analyses' in Supplement 1 at www.int-res.com/articles/suppl/m602 p169_supp.pdf.

\section{RESULTS}

Mean values, averaged over fresh mass, of HSI, TL, and the dietary indices $\mathrm{I}_{\mathrm{Ca}}, \mathrm{I}_{\mathrm{Ch}}, \mathrm{I}_{\mathrm{P}}, \mathrm{I}_{\mathrm{R}}$, and $\mathrm{I}_{\mathrm{B}}$ are presented in Table 2. Detailed figures for the dietary indices in relation to fresh mass are shown in Figs. S2-S6 of Supplement 1. Statistical results are summarized in Table 3. Here, we focus on the results of interactions that include the factor 'species'. Interactions excluding this factor (e.g. Sex $\times$ Month $\times$ Fresh mass) were not meaningful in view of the aims and questions of our study.

\section{HSI}

Carcinus maenas and Hemigrapsus sanguineus showed different seasonal patterns in HSI. C. maenas exhibited the highest average HSIs in April and June. The values decreased in August and October (Table 2, Fig. 1A,B). In contrast, H. sanguineus showed no significant differences in the average HSI between seasons (Table 2, Fig. 1C,D). Furthermore, differently sized $C$. maenas showed the same HSI, and a negative relationship between HSI and fresh mass was only found in $H$. sanguineus from June and August.

\section{TL content}

The midgut glands of $H$. sanguineus had higher TL contents than those of C. maenas (Table 2, Fig. 2). 


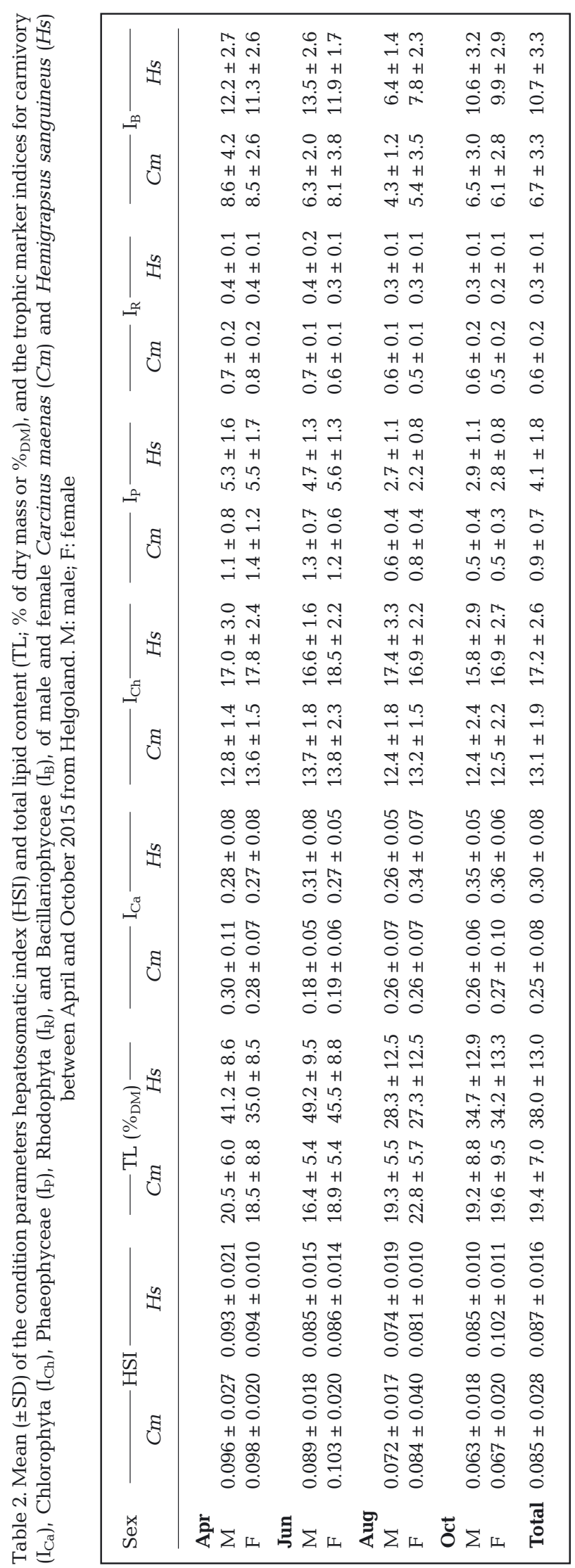

When sexes were combined, the species showed different seasonal relationships between TL and fresh mass. TL levels did not change with fresh mass in $C$. maenas, but showed a significant negative correlation in August and October for H. sanguineus. Pooled over fresh mass, C. maenas showed quite similar average TL levels in all seasons, but for $H$. sanguineus, values differed remarkably between seasons. When pooled by sex, C. maenas males showed slightly lower TL values than females (pooled over all other factors: $18.8 \pm 6.6 \% \mathrm{DM}$ vs. $20.0 \pm 7.4 \% \mathrm{DM}$, respectively), whereas in $H$. sanguineus, the males had higher TL values than the females (39.3 \pm $13.3 \%$ DM Vs. $36.7 \pm 12.5 \%{ }_{D M}$, respectively).

\section{FA composition}

Mean FA compositions of the midgut glands of both crab species and the macroalgae are presented in Table 4, and the corresponding raw data are presented in Table S1 (see Supplement 2 at www.int-res. com/articles/suppl/m602p169_supp.xlsx).

The main FAs in the midgut glands of $C$. maenas and $H$. sanguineus were 16:0, 20:5(n-3), 18:1(n-9), and 16:1(n-7) (Table 4). Summarized over all months and fresh masses, C. maenas showed lower values of 16:0, 16:4(n-3), 18:1(n-9), and 18:3(n-3) than H. sanguineus (Table 4). In contrast, the FAs 18:0, 20:1(n-11), 20:1(n-7), and especially 20:5(n-3) were higher in $C$. maenas.

The macroalgae showed group-specific patterns as described by Kelly \& Scheibling (2012) (our Table 4). The Chlorophyta Ulva sp. was richest in 16:0. Other prevalent FAs were 18:3(n-3), 16:4(n-3), and 18:1(n-7). The 3 species of Phaeophyceae were richest in 16:0, 18:1(n-9), 20:4(n-6), 18:2(n-6), 14:0, and 20:5(n-3). In Fucus serratus, 18:1(n-9) dominated with about $32.0 \%$, whereas it comprised only about $7.7 \%$ and $18.4 \%$ in Sargassum muticum and Desmarestia aculeata, respectively. The 4 species of Rhodophyta were rich in 20:5(n-3), 16:0, 20:4(n-6), and 18:1(n-9). Within this group, Ceramium virgatum and Corallina officinalis showed comparably low values of 20:4(n-6), but high values of 20:5(n-3).

PCAs of the FA composition were conducted separately for males and females of either species in each of the 4 months. They did not show sex-specific differences within species. Furthermore, the PCAs conducted separately for the 2 crab species and pooling the sexes did not show season-specific differences. Only the PCA for $H$. sanguineus showed an arrangement of samples separating April and June 


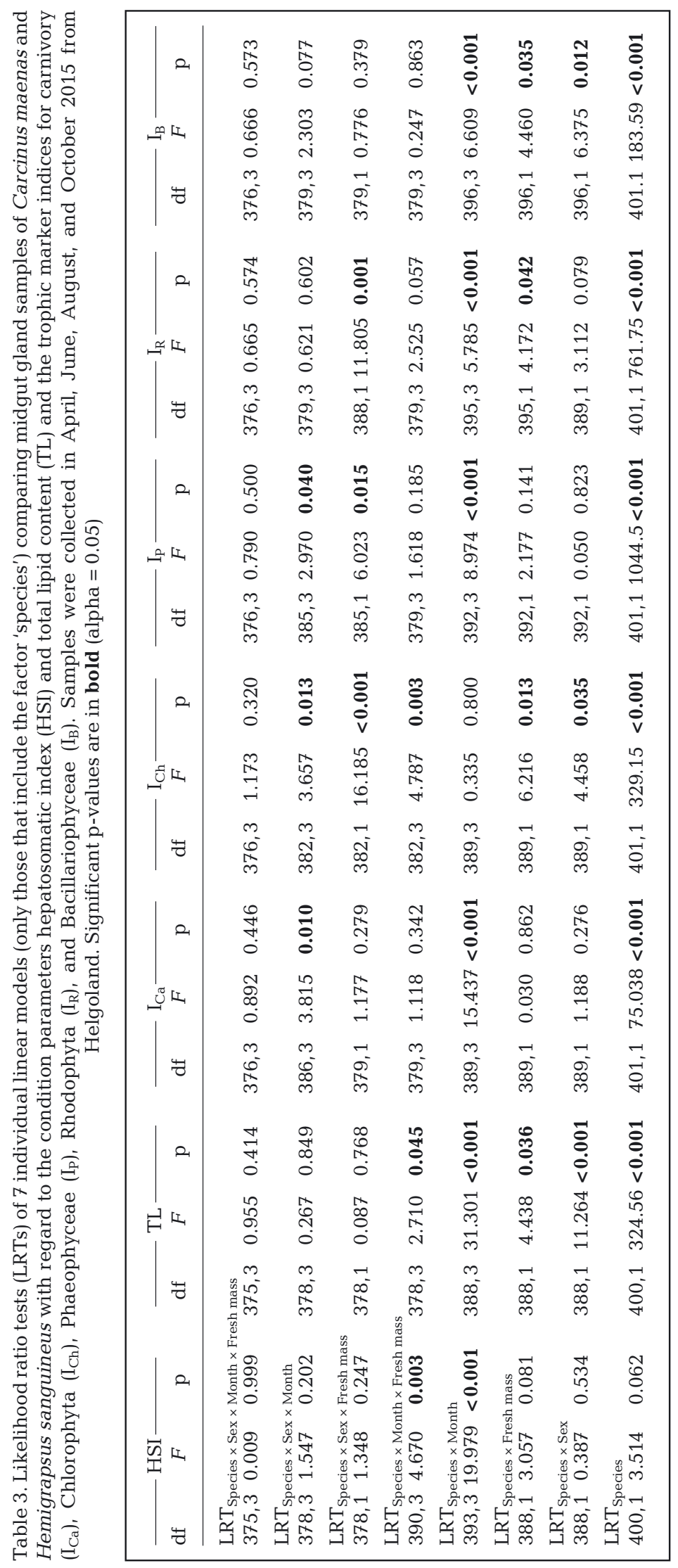

from August and October (Fig. S1 in Supplement 1).

The PCA of the FA compositions of all crab and macroalgae tissues revealed distinct clusters for C. maenas and H. sanguineus. Likewise, the FA of the macroalgae formed distinct groups and clearly separated from the crab species as well as from each other (Fig. 3). The first 3 principal components (PCs) accounted for about $68 \%$ of the variance, while the first 2 together explained about $58 \%$. The main contributing eigenvectors of $\mathrm{PC} 1$ were, in decreasing order, 18:4(n-3), 18:3(n-3), 16:2(n-4), and 16:1(n-7) with positive values, as well as 20:5(n-3), 18:0, 20:1(n-11), and 20:1(n-7) with negative values. PC2 was mostly characterized by positive values of 20:4(n-6) and 20:5(n-3), as well as by negative values of 16:1(n-7), 22:5(n-3), 18:1(n-7), and 20:1(n-7), again in decreasing order.

\section{Carnivory index $\left(\mathrm{I}_{\mathrm{Ca}}\right)$}

Levels of $\mathrm{I}_{\mathrm{Ca}}$ were higher in $H$. sanguineus than in C. maenas and showed significantly differing seasonal patterns between the 2 species (Table 2, Fig. S2). Males and females of $C$. maenas showed similar seasonal patterns. In June, the average $\mathrm{I}_{\mathrm{Ca}}$ was lower than in the other months. In H. sanguineus, males showed similar average $\mathrm{I}_{\mathrm{Ca}}$ values in April, June, and August, but an increase in October. In female $H$. sanguineus, $\mathrm{I}_{\mathrm{Ca}}$ levels were similar in April and June, increased in August, and remained at this level in October.

\section{Chlorophyta index $\left(\mathrm{I}_{\mathrm{Ch}}\right)$}

$H$. sanguineus showed higher $\mathrm{I}_{\mathrm{Ch}}$ levels than C. maenas (Table 2, Fig. S3). Only $H$. sanguineus females showed a positive correlation between $\mathrm{I}_{\mathrm{Ch}}$ and fresh mass. When pooled over sexes, the 2 species also differed in their seasonal relationship of $\mathrm{I}_{\mathrm{Ch}}$ with fresh mass. Then, only $H$. sanguineus individuals from October showed a positive $\mathrm{I}_{\mathrm{Ch}}$ correlation to fresh mass, in contrast to all other $H$. sanguineus and all C. maenas individuals. When all different sizes were 

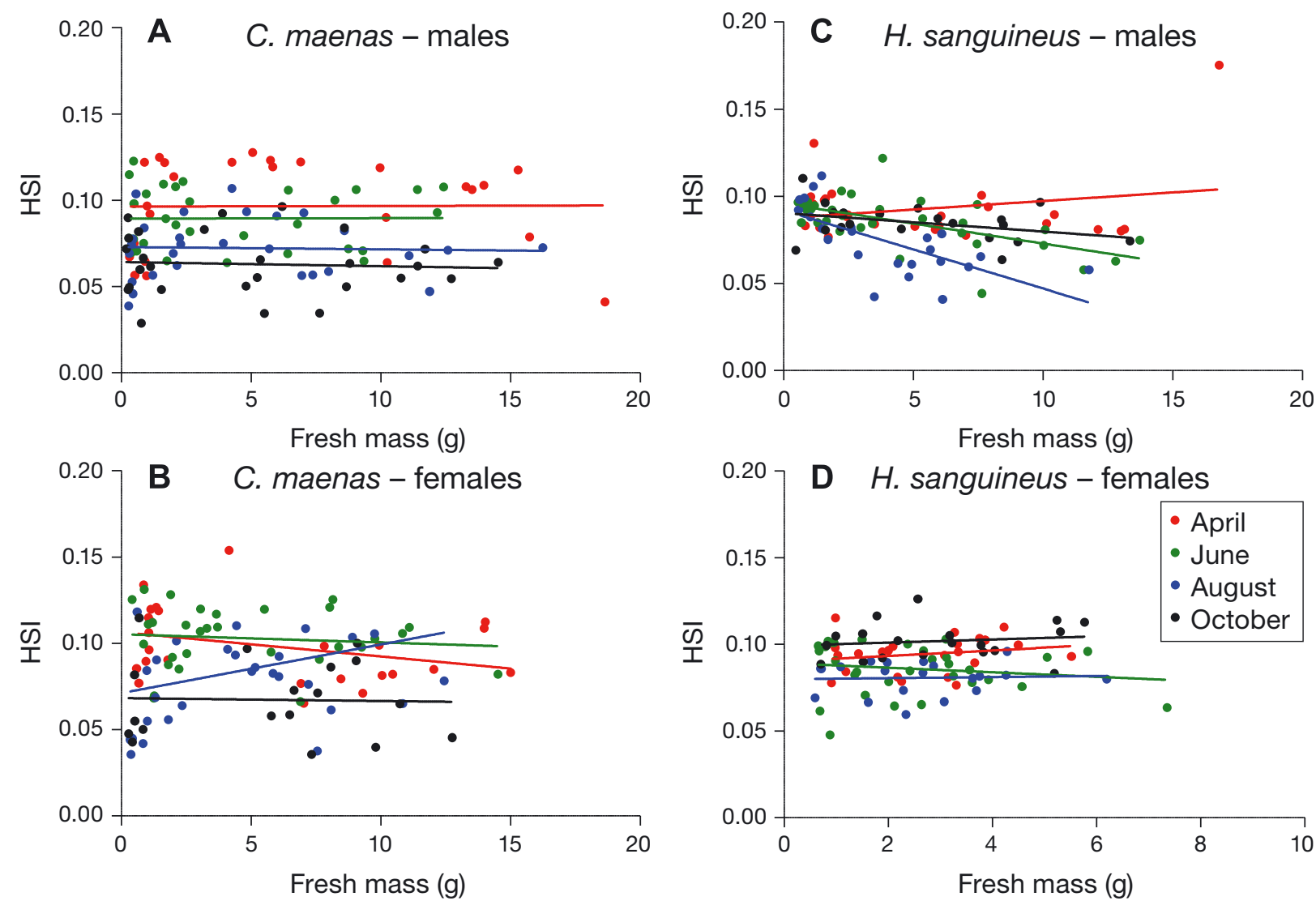

Fig. 1. Hepatosomatic indices (HSI) of Carcinus maenas (A) males and (B) females and Hemigrapsus sanguineus (C) males and (D) females sampled at Helgoland between April and October 2015. Note the differing $x$-axis of (D). For the calculation of HSI, see Table 1

combined, the 2 species differed in their seasonal pattern between species and sex. Pooling the different months and sexes revealed that $\mathrm{I}_{\mathrm{Ch}}$ levels of $H$. sanguineus specimens were correlated to fresh mass, whereas this was not the case in C. maenas.

\section{Phaeophyceae index $\left(I_{P}\right)$}

Levels of $\mathrm{I}_{\mathrm{P}}$ were higher in $H$. sanguineus than in $C$. maenas (Table 2, Fig. S4). For males, a similar pattern was detected in both species: similar levels in April and June, a decrease towards August, followed by a similar level in October. The seasonal patterns in female $H$. sanguineus were similar to that of males. Females of $C$. maenas showed a decrease from August to October. Additionally, when both sexes and fresh masses were pooled, the 2 species differed in their seasonal $\mathrm{I}_{\mathrm{P}}$ patterns. Only females of $H$. sanguineus showed a positive correlation between $\mathrm{I}_{\mathrm{P}}$ and fresh mass. No correlation occurred in H. sanguineus males and in both sexes of $C$. maenas.

\section{Rhodophyta index $\left(\mathrm{I}_{\mathrm{R}}\right)$}

Overall, values of $\mathrm{I}_{\mathrm{R}}$ were lower in $H$. sanguineus than in C. maenas (Table 2, Fig. S5). Only the $\mathrm{I}_{\mathrm{R}}$ values of $H$. sanguineus females showed a negative correlation with fresh mass. When the data were pooled over months and sexes, a negative relationship of $I_{R}$ and fresh mass was found for $H$. sanguineus but not for C. maenas. Values of C. maenas were similar in April and June, decreased in August, and remained at the same level in October. In $H$. sanguineus, $I_{R}$ decreased from April to June and August and again to October.

\section{Bacillariophyceae index $\left(\mathrm{I}_{B}\right)$}

Values of $\mathrm{I}_{\mathrm{B}}$ were higher in $H$. sanguineus than in C. maenas (Table 2, Fig. S6). C. maenas showed decreasing values from April to August and an increase in October. In contrast, $H$. sanguineus had similar $\mathrm{I}_{\mathrm{B}}$ values in April and June, decreasing values in 

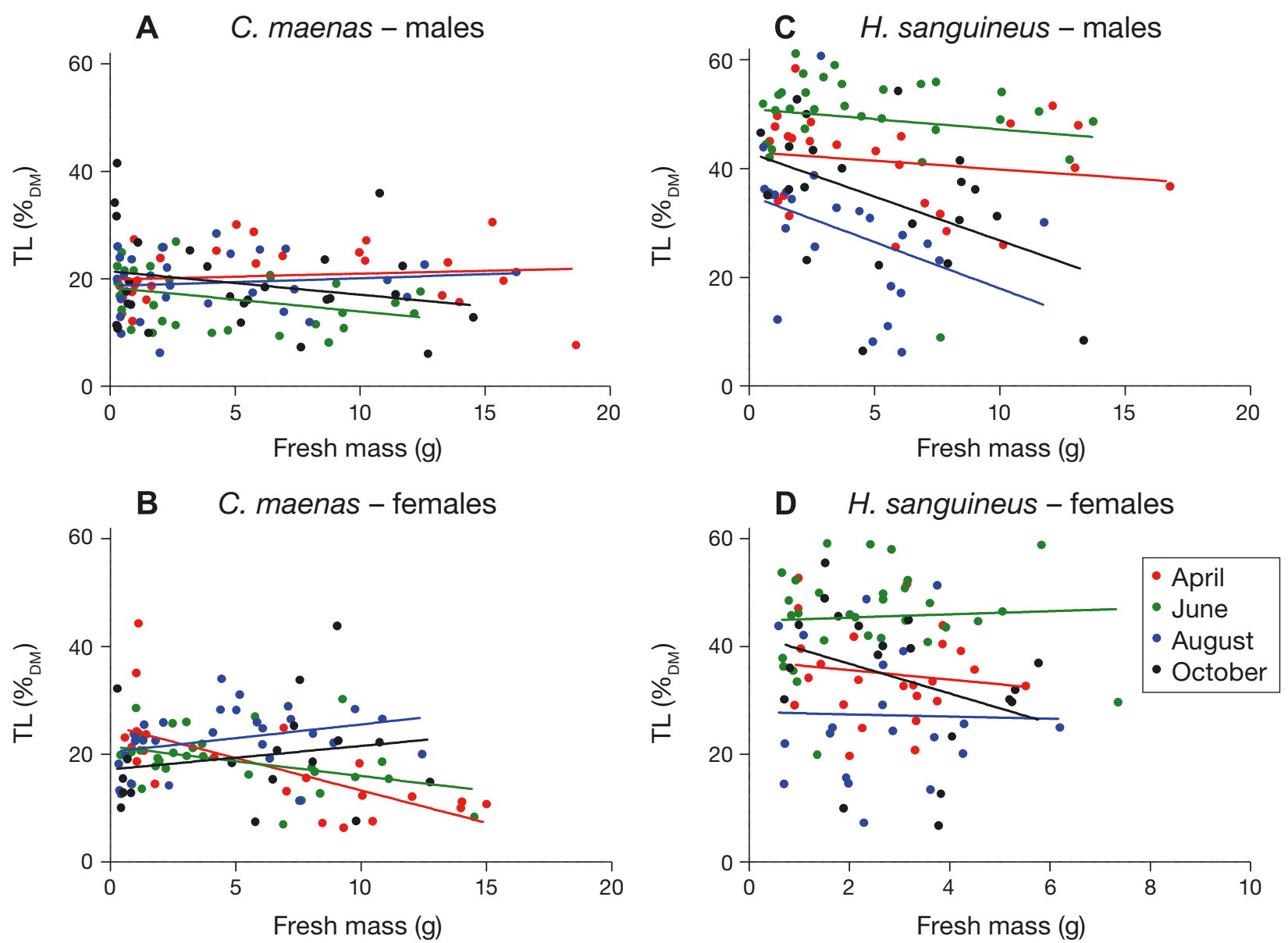

Fig. 2. Total lipid content (TL; \% of dry mass or \% ${ }_{\mathrm{DM}}$ ) of Carcinus maenas (A) males and (B) females and Hemigrapsus sanguineus (C) males and (D) females sampled at Helgoland between April and October 2015. Note the differing $x$-axis of (D). For the calculation of TL, see Table 1

August, followed by an increase to October. When pooled over month and fresh mass, C. maenas males had lower $I_{B}$ values than females $(6.4 \pm 3.1$ and $7.1 \pm$ 3.5 , respectively). The opposite occurred in $H$. sanguineus males and females $(11.0 \pm 3.7$ and $8.6 \pm 4.9$, respectively). Positive correlations between $\mathrm{I}_{\mathrm{B}}$ and fresh mass were present in both sexes of C. maenas, but not in H. sanguineus.

\section{DISCUSSION}

\section{Energy storage}

We used HSI and TL as measures for the energy storage capacities of Carcinus maenas and Hemigrapsus sanguineus. HSI values were in the same range as reported previously for these 2 species from the east coast of North America (0.02-0.13 for both species; Griffen et al. 2011, 2012). TL values were in a range reported previously for C. maenas (Aagaard
1996, Styrishave \& Andersen 2000) and H. sanguineus (Griffen et al. 2015). The TL levels for H. sanguineus showed a strong seasonal pattern, whereas TL values of $C$. maenas did not differ between seasons around Helgoland, which is in contrast to observations from Denmark (Styrishave \& Andersen 2000).

Energy stores are required when animals need to overcome periods of food scarcity, e.g. low-production seasons, or when energy stores are used for reproduction (Kyomo 1988, Kucharski \& Da Silva 1991, Kennish 1997, Yamaguchi 2004, Lee et al. 2006, Alava et al. 2007, Barrento et al. 2009). The difference in the annual TL patterns cannot be explained by the differing reproductive strategies described for C. maenas ('capital breeder') and $H$. sanguineus ('income breeder') (Griffen et al. 2011, 2012). These strategies would result in TL levels with and without seasonality, respectively; however we detected the opposite.

Our results may be explained by the huge difference in lipid turnover between both species. Around Helgoland, the reproductive period of $H$. sanguineus 


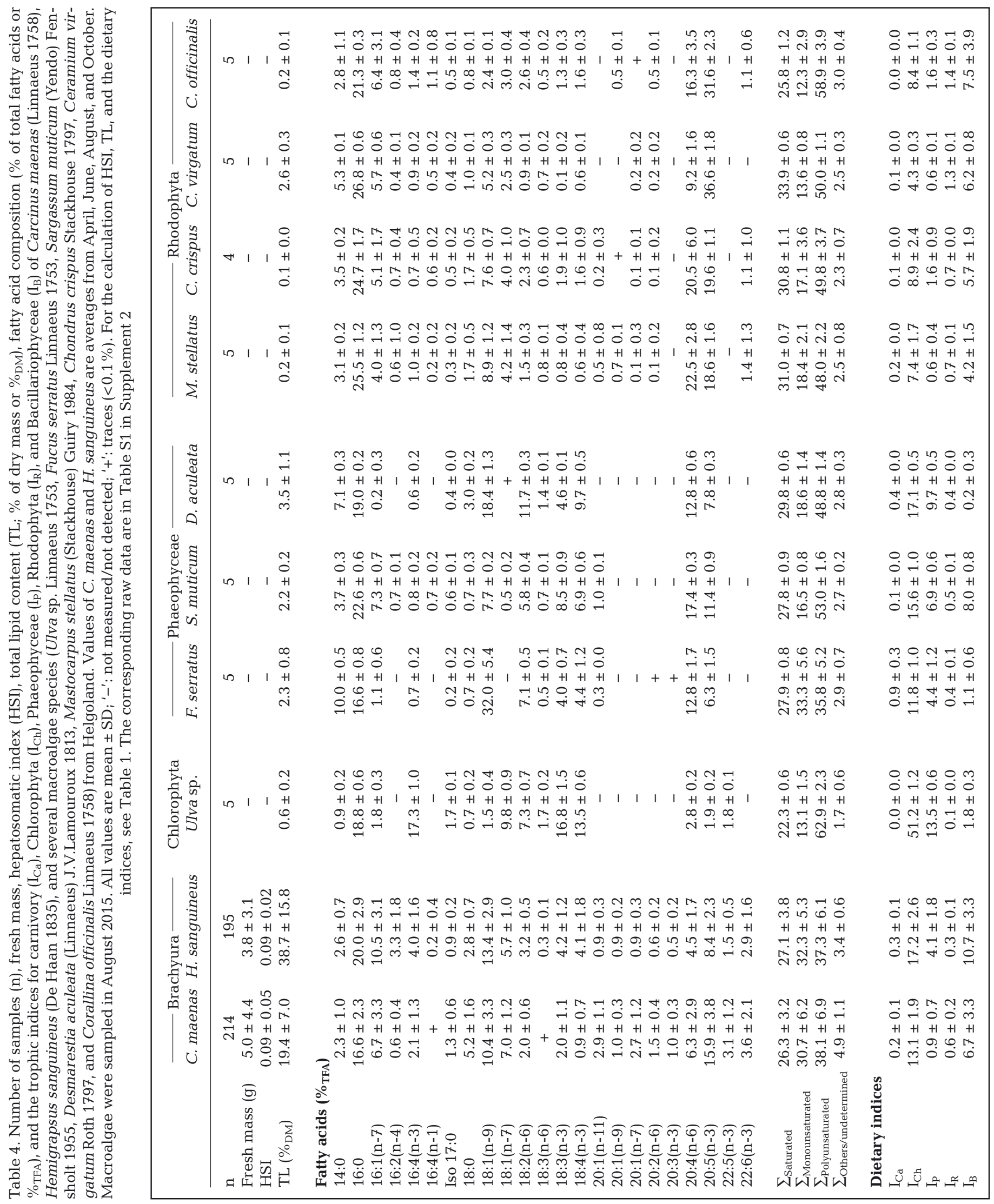




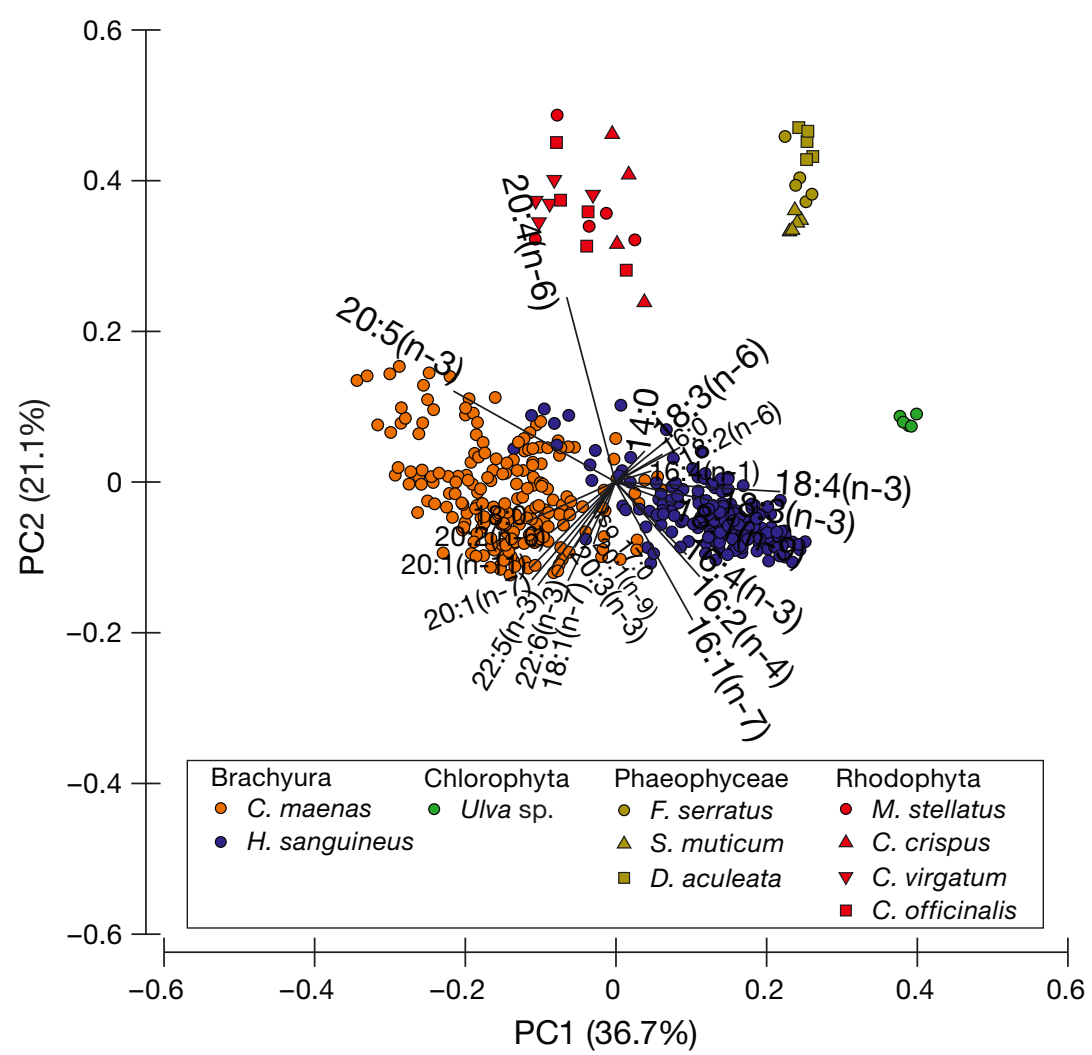

Fig. 3. Principal component analysis of fatty acid composition of hepatopancreas samples of Carcinus maenas and Hemigrapsus sanguineus, and of different macroalgae species (Ulva sp., Fucus serratus, Sargassum muticum, Desmarestia aculeata, Mastocarpus stellatus, Chondrus crispus, Ceramium virgatum, and Corallina officinalis) sampled at Helgoland in 2015

covers at least 5 mo (June to October), when they produce up to 5 lipid-rich $\left(28 \%_{\text {DM }}\right)$ egg clutches, together comprising $42 \%$ of their body mass (Fukui 1988, M. L. McCarthy \& S. Jungblut unpubl. data). In contrast, C. maenas produce only 1 egg clutch (less lipid-rich, at around $\left.23 \%_{\mathrm{DM}}\right)$ in their shorter reproductive period (April to June) (Klassen \& Locke 2007, M. L. McCarthy \& S. Jungblut unpubl. data). Thus, $H$. sanguineus females invest in higher egg quantity and quality, leading to seasonally increased lipid reserves, usually accumulated as triacylglycerols (S. Jungblut unpubl. data).

The cause of the seasonal TL pattern in male $H$. sanguineus remains unknown. There is no evidence of, e.g., energy-demanding mating behavior like in $C$. maenas (Styrishave \& Andersen 2000) or interrupted feeding during the mating season.

Energy storage levels likely depend on the amount and quality of the ingested diet. Higher HSI and TL levels occurred in both species when fed with animal diet instead of algae (Griffen et al. 2011, 2012, Griffen 2017). To store larger amounts of lipids, e.g. for reproductive efforts, $H$. sanguineus might ingest more food or increase carnivory to compensate for the low energy content of the usually preferred algae material.

\section{FA composition of midgut glands}

No distinct differences in FA composition in relation to sex or seasons were detected in each of the 2 species. Other studies, however, have reported variable FA compositions, which were attributed to ovarian maturation, sex, seasons, temperature, and, in case of C. maenas, color morph (Chapelle 1978, Styrishave \& Andersen 2000, Alava et al. 2007, Barrento et al. 2009).

The FA composition of the midgut glands of $C$. maenas and $H$. sanguineus formed 2 well-separated clusters in the PCA, which may partly be due to the large differences in TL levels. The cluster of C. maenas is oriented towards the direction of 3 membrane FAs, 18:0, 20:5(n-3), and 22:6(n-3), because the TL levels were rather low and hence biomembrane FAs prevail. The carnivory-indicating FA 18:1(n-9) is directed towards the samples of $H$. sanguineus. At first glance, this could indicate a higher degree of carnivory; however, Phaeophyceae were also rich in 18:1(n-9), especially Fucus serratus and Desmarestia aculeata. This illustrates that $\mathrm{I}_{\mathrm{Ca}}$ cannot be used for dietary interpretation alone (see 'Materials and methods').

\section{Dietary preferences}

The example of the FA 18:1(n-9) emphasizes the need for closer examination of the dietary preferences of $C$. maenas and $H$. sanguineus as well as benthic animals in general. Each of the 5 taxonspecific FA trophic marker indices clearly showed differences between the 2 species. For some indices, differences were also found between seasons, between sexes, and among different sizes of crabs. These differences, however, did not follow consistent trends. Similarly, the few studies on the stomach contents of differently sized C. maenas showed inconsistent results (Ropes 1968, 1988, Elner 1981, Baeta et 
al. 2006). Therefore, we encourage FATM analyses as the intermediate way between biased short-term gut content studies and rather unspecific long-term stable isotope analyses, to evaluate complex dietary preferences and to explore competition for food in co-occurring crabs (Graeve et al. 2001, Latyshev et al. 2004, Griffen 2014).

Except for Rhodophyta, all dietary indices of algae were higher in $H$. sanguineus, indicating a higher level of herbivory. The intense consumption of Phaeophyceae, rich in 18:1(n-9), is most likely the reason for the high - yet misleading — values of the carnivory index in $H$. sanguineus. These dietary preferences are all corroborated by laboratory experiments, gut content analyses, and studies on gut morphology (e.g. Eriksson \& Edlund 1977, Birch 1979, Pihl 1985, Tyrrell \& Harris 1999, Brousseau \& Goldberg 2007, Griffen et al. 2008, 2011, Griffen \& Mosblack 2011).

Competition for food between C. maenas and $H$. sanguineus is probably low in macroalgae-rich habitats. So far, the trophic impact of $H$. sanguineus has mostly been evaluated for potential animal prey organisms like barnacles, mytilid mussels, or littorinid snails (e.g. Lohrer et al. 2000, Lohrer \& Whitlatch 2002, Brousseau \& Baglivo 2005, Tyrrell et al. 2006, Brousseau \& Goldberg 2007, Brousseau et al. 2014). Only a few studies have considered the more likely case: the impact of $H$. sanguineus on the algal community (Tyrrell \& Harris 1999). Unlike C. maenas, the European individuals of $H$. sanguineus do not retreat to subtidal areas or bury in the sediment in winter (Janke 1986, Aagaard et al. 1995). H. sanguineus is present and forages in the intertidal area during the whole year (R. Saborowski unpubl. data). This foraging pressure may reduce the winter recruitment success of, e.g., Phaeophyceae in the invaded habitats. Given the macroalgae richness, this effect may be weak around Helgoland. For macroalgae-poor habitats like the Wadden Sea, however, the competition for food between $C$. maenas and $H$. sanguineus and the effect of $H$. sanguineus on Phaeophyceae might be significant.

\section{CONCLUSIONS}

We demonstrated that Hemigrapsus sanguineus stored much higher amounts of lipids as energy reserves than Carcinus maenas (hypothesis 1 supported). In contrast to $C$. maenas, $H$. sanguineus showed a pronounced seasonality in lipid deposition and depletion (hypothesis 2 rejected). These differences may be due to the higher lipid turnover in $H$. sanguineus. The
FA composition of $C$. maenas and $H$. sanguineus differed distinctly from one another (hypothesis 3i supported), but within each species, no differences with respect to sex or seasons became apparent (hypotheses 3ii and 3iii rejected). $H$. sanguineus was able to accumulate high lipid quantities in relatively short periods, apparently exploiting macroalgae as a primary resource. The dietary indices for Chlorophyta, Bacillariophyceae, and especially Phaeophyceae were higher for $H$. sanguineus than for C. maenas (hypothesis $4 \mathrm{i}$ supported). Only the Rhodophyta index suggested a higher consumption of red algae by $C$. maenas. There were no species-specific patterns in dietary preferences with regard to crab size, sex, and season (hypotheses 4ii, 4iii, and 4iv undecided). The competition for food between $H$. sanguineus and $C$. maenas may be low in macroalgae-rich habitats. Overall, our data suggest that $H$. sanguineus is clearly more herbivorous, apparently occupying quite a different trophic niche than $C$. maenas. Even though it consumes energy-poor macroalgae, $H$. sanguineus is able to accumulate large lipid reserves. These deposits buffer periods of food paucity, facilitates reproductive output, and thus contributes to the success of this invasive crab in new areas.

Acknowledgements. We thank the staff of the Biologische Anstalt Helgoland and especially Dr. Jan Beermann for laboratory space and for support, whenever needed, and Dominik A. Nachtsheim as well as 4 anonymous reviewers for valuable editorial support. This study was partly supported by a RISE internship grant from the DAAD (German Academic Exchange Service) to M.L.M.

\section{LITERATURE CITED}

Aagaard A (1996) In situ variation in heart rate of the shore crab Carcinus maenas in relation to environmental factors and physiological condition. Mar Biol 125:765-772

Aagaard A, Warman CG, Depledge MH (1995) Tidal and seasonal changes in the temporal and spatial distribution of foraging Carcinus maenas in the weakly tidal littoral zone of Kerteminde Fjord, Denmark. Mar Ecol Prog Ser 122:165-172

Alava VR, Quinitio ET, de Pedro JB, Priolo FMP, Orozco ZGA, Wille $M$ (2007) Lipids and fatty acids in wild and pondreared mud crab Scylla serrata (Forsskål) during ovarian maturation and spawning. Aquacult Res 38:1468-1477

Baeta A, Cabral HN, Marques JC, Pardal MA (2006) Feeding ecology of the green crab, Carcinus maenas (L., 1758) in a temperate estuary, Portugal. Crustaceana 79: 1181-1193

Barrento S, Marques A, Teixeira B, Anacleto P, Vaz-Pires P, Nunes ML (2009) Effect of season on the chemical composition and nutritional quality of the edible crab Cancer pagurus. J Agric Food Chem 57:10814-10824

Bartsch I, Tittley I (2004) The rocky intertidal biotopes of 
Helgoland: present and past. Helgol Mar Res 58:289-302

Birch DW (1979) Food preferences of Hemigrapsus nudus (Dana, 1851) (Decapoda, Grapsidae) on San Juan Island, Washington, USA. Crustaceana 36:186-188

Bode M, Hagen W, Schukat A, Teuber L, Fonseca-Batista D, Dehairs F, Auel H (2015) Feeding strategies of tropical and subtropical calanoid copepods throughout the eastern Atlantic Ocean - latitudinal and bathymetric aspects. Prog Oceanogr 138:268-282

Boissonnot L, Niehoff B, Hagen W, Søreide JA, Graeve M (2016) Lipid turnover reflects life-cycle strategies of smallsized Arctic copepods. J Plankton Res 38:1420-1432

Breton G, Faasse M, Noël P, Vincent P (2002) A new alien crab in Europe: Hemigrapsus sanguineus (Decapoda: Brachyura: Grapsidae). J Crustac Biol 22:184-189

Brockerhoff A, McLay C (2011) Human mediated spread of alien crabs. In: Galil B, Clark P, Carlton J (eds) In the wrong place-alien marine crustaceans: distribution, biology and impacts. Springer Science+Business Media, Dordrecht, p 27-106

Brousseau DJ, Baglivo JA (2005) Laboratory investigations of food selection by the Asian shore crab, Hemigrapsus sanguineus: algal versus animal preference. J Crustac Biol 25:130-134

Brousseau DJ, Goldberg R (2007) Effect of predation by invasive crab Hemigrapsus sanguineus on recruiting barnacles Semibalanus balanoides in western Long Island Sound, USA. Mar Ecol Prog Ser 339:221-228

* Brousseau DJ, Goldberg R, Garza C (2014) Impact of predation by the invasive crab Hemigrapsus sanguineus on survival of juvenile blue mussels in western Long Island Sound. Northeast Nat 21:119-133

* Carlton JT, Cohen AN (2003) Episodic global dispersal in shallow water marine organisms: the case history of the European shore crabs Carcinus maenas and C. aestuarii. J Biogeogr 30:1809-1820

* Chapelle S (1978) The influence of acclimation temperature on the fatty acid composition of an aquatic crustacean (Carcinus maenas). J Exp Zool 204:337-346

Clarke KR, Warwick RM (1994) Changes in marine communities: an approach to statistical analysis and interpretation. Plymouth Marine Laboratory, Natural Environment Research Council (NERC), Plymouth

Colautti RI, Ricciardi A, Grigorovich IA, MacIsaac HJ (2004) Is invasion success explained by the enemy release hypothesis? Ecol Lett 7:721-733

* Dalsgaard J, St John M, Kattner G, Müller-Navarra D, Hagen W (2003) Fatty acid trophic markers in the pelagic marine environment. Adv Mar Biol 46:225-340

Welaney DG, Sperling CD, Adams CS, Leung B (2008) Marine invasive species: validation of citizen science and implications for natural monitoring networks. Biol Invasions 10:117-128

Didham RK, Tylianakis JM, Hutchison MA, Ewers RM, Gemmell NJ (2005) Are invasive species the drivers of ecological change? Trends Ecol Evol 20:470-474

Elner RW (1981) Diet of green crab Carcinus maenas (L.) from Port Herbert, southwestern Nova Scotia. J Shellfish Res 1:89-94

Elton CS (1958) The ecology of invasion by plants and animals. Methuen, London

Epifanio CE (2013) Invasion biology of the Asian shore crab Hemigrapsus sanguineus: a review. J Exp Mar Biol Ecol 441:33-49
Eriksson S, Edlund AM (1977) On the ecological energetics of 0-group Carcinus maenas (L.) from a shallow sandy bottom in Gullmar Fjord, Sweden. J Exp Mar Biol Ecol 30:233-248

Folch J, Lees M, Sloane-Stanley GH (1957) A simple method for the isolation and purification of total lipids from animal tissues. J Biol Chem 226:497-509

* Fukui Y (1988) Comparative studies on the life history of grapsid crabs (Crustacea, Brachyura) inhabiting intertidal cobble and boulder shores. Publ Seto Mar Biol Lab 33:121-162

* Graeve M, Dauby P, Scailteur Y (2001) Combined lipid, fatty acid and digestive tract content analyses: a penetrating approach to estimate feeding modes of Antarctic amphipods. Polar Biol 24:853-862

* Griffen BD (2014) Linking individual diet variation and fecundity in an omnivorous marine consumer. Oecologia 174:121-130

* Griffen BD (2017) Metabolic costs of capital energy storage in a small-bodied ectotherm. Ecol Evol 7:2423-2431

G Griffen BD, Mosblack H (2011) Predicting diet and consumption rate differences between and within species using gut ecomorphology. J Anim Ecol 80:854-863

Griffen BD, Guy T, Buck JC (2008) Inhibition between invasives: a newly introduced predator moderates the impacts of a previously established invasive predator. J Anim Ecol 77:32-40

Griffen BD, Altman I, Hurley J, Mosblack H (2011) Reduced fecundity by one invader in the presence of another: a potential mechanism leading to species replacement. J Exp Mar Biol Ecol 406:6-13

* Griffen BD, Altman I, Bess BM, Hurley J, Penfield A (2012) The role of foraging in the success of invasive Asian shore crabs in New England. Biol Invasions 14:2545-2558

* Griffen BD, Vogel M, Goulding L, Hartman R (2015) Energetic effects of diet choice by invasive Asian shore crabs: implications for persistence when prey is scarce. Mar Ecol Prog Ser 522:181-192

Grosholz E (2002) Ecological and evolutionary consequences of coastal invasions. Trends Ecol Evol 17:22-27

Gurevitch J, Padilla DK (2004) Are invasive species a major cause of extinctions? Trends Ecol Evol 19:470-474

Hagen W (2000) Lipids. In: Harris R, Wiebe R, Lenz J, Skjøldal H, Huntley M (eds) ICES zooplankton methodology manual. Academic Press, San Diego, CA, p 113-119

Janke K (1986) Die Makrofauna und ihre Verteilung im Nordost-Felswatt von Helgoland. Helgol Meeresunters 40:1-55

Jimenez AG, Kinsey ST (2015) Energetics and metabolic regulation. In: Chang ES, Thiel $M$ (eds) The natural history of the Crustacea, Vol 4: Physiology. Oxford University Press, Oxford, p 391-419

* Jungblut S, Beermann J, Boos K, Saborowski R, Hagen W (2017) Population development of the invasive crab Hemigrapsus sanguineus (De Haan, 1853) and its potential native competitor Carcinus maenas (Linnaeus, 1758) at Helgoland (North Sea) between 2009 and 2014. Aquat Invasions 12:85-96

Kattner G, Fricke HSG (1986) Simple gas-liquid chromatographic method for the simultaneous determination of fatty acids and alcohols in wax esters of marine organisms. J Chromatogr A 361:263-268

Kelley AL (2014) The role thermal physiology plays in species invasions. Conserv Physiol 2:cou045 
Kelly JR, Scheibling RE (2012) Fatty acids as dietary tracers in benthic food webs. Mar Ecol Prog Ser 446:1-22

Kennish R (1997) Seasonal patterns of food availability: influences on the reproductive output and body condition of the herbivorous crab Grapsus albolineatus. Oecologia 109:209-218

Klassen G, Locke A (2007) A biological synopsis of the European green crab, Carcinus maenas. Can Manuscr Rep Fish Aquat Sci 2818:1-75

Kolar CD, Lodge DM (2001) Progress in invasion biology: predicting invaders. Trends Ecol Evol 16:199-204

Kucharski LCR, Da Silva RSM (1991) Seasonal variation in the energy metabolism in an estuarine crab, Chasmagnathus granulata (Dana, 1851). Comp Biochem Physiol A 100:599-602

Kyomo J (1988) Analysis of the relationship between gonads and hepatopancreas in males and females of the crab Sesarma intermedia, with reference to resource use and reproduction. Mar Biol 97:87-93

Landschoff J, Lackschewitz D, Kesy K, Reise K (2013) Globalization pressure and habitat change: Pacific rocky shore crabs invade armored shorelines in the Atlantic Wadden Sea. Aquat Invasions 8:77-87

Latyshev NA, Khardin AS, Kasyanov SP, Ivanova MB (2004) A study on the feeding ecology of chitons using analysis of gut contents and fatty acid markers. J Molluscan Stud 70:225-230

Lee RF, Hagen W, Kattner G (2006) Lipid storage in marine zooplankton. Mar Ecol Prog Ser 307:273-306

Lewis EG, Haefner PA (1976) Oxygen consumption of the blue crab, Callinectes sapidus Rathbun, from proecdysis to postecdysis. Comp Biochem Physiol A 54:55-60

Lodge DM (1993) Biological invasions: lessons for ecology. Trends Ecol Evol 8:133-137

Kohrer AM, Whitlatch RB (2002) Relative impacts of two exotic brachyuran species on blue mussel populations in Long Island Sound. Mar Ecol Prog Ser 227:135-144

Lohrer AM, Whitlatch RB, Wada K, Fukui Y (2000) Home and away: comparisons of resource utilization by a marine species in native and invaded habitats. Biol Invasions 2:41-57

Naylor JK, Taylor EW, Bennett DB (1997) The oxygen uptake of ovigerous edible crabs (Cancer pagurus) (L.) and their eggs. Mar Freshw Behav Physiol 30:29-44

Obert B, Herlyn M, Grotjahn M (2007) First records of two crabs from the North West Pacific Hemigrapsus sanguineus and $H$. takanoi at the coast of Lower Saxony, Germany. Wadden Sea Newsl 1:21-22

O'Connor NJ (2014) Invasion dynamics on a temperate rocky shore: from early invasion to establishment of a marine invader. Biol Invasions 16:73-87

Pihl L (1985) Food selection and consumption of mobile epibenthic fauna in shallow marine areas. Mar Ecol Prog Ser 22:169-179

R Development Core Team (2015) R: a language and environment for statistical computing. $\mathrm{R}$ Foundation for Statistical Computing, Vienna. www.R-project.org

Ropes JW (1968) The feeding habits of the green crab, Carcinus maenas (L.). Fish Bull 67:183-203
Ropes JW (1988) The food habits of five crab species at Pettaquamscutt River, Rhode Island. Fish Bull 87:197-204

* Ruiz GM, Fofonoff PW, Carlton JT, Wonham MJ, Hines AH (2000) Invasion of coastal marine communities in North America: apparent patterns, processes, and biases. Annu Rev Ecol Evol Syst 31:481-531

* Russell LK, Hepburn CD, Hurd CL, Stuart MD (2008) The expanding range of Undaria pinnatifida in southern New Zealand: distribution, dispersal mechanisms and the invasion of wave-exposed environments. Biol Invasions 10:103-115

Saborowski R (2015) Nutrition and digestion. In: Chang ES, Thiel M (eds) The natural history of the Crustacea, Vol 4: Physiology. Oxford University Press, Oxford, p 285-319

* Sakai AK, Allendorf FW, Holt JS, Lodge DM and others (2001) The population biology of invasive species. Annu Rev Ecol Syst 32:305-332

* Schukat A, Auel H, Teuber L, Lahajnar N, Hagen W (2014) Complex trophic interactions of calanoid copepods in the Benguela upwelling system. J Sea Res 85:186-196

* Shea K, Chesson P (2002) Community ecology theory as a framework for biological invasions. Trends Ecol Evol 17: 170-176

Simberloff D, Martin JL, Genovesi P, Maris V and others (2013) Impacts of biological invasions: what's what and the way forward. Trends Ecol Evol 28:58-66

* Stephenson EH, Steneck RS, Seeley RH (2009) Possible temperature limits to range expansion of non-native Asian shore crabs in Maine. J Exp Mar Biol Ecol 375:21-31

Styrishave B, Andersen O (2000) Seasonal variations in hepatopancreas fatty acid profiles of two colour forms of shore crabs, Carcinus maenas. Mar Biol 137:415-422

Styrishave B, Rewitz K, Andersen O (2004) Frequency of moulting by shore crabs Carcinus maenas (L.) changes their colour and their success in mating and physiological performance. J Exp Mar Biol Ecol 313:317-336

Tyrrell MC, Harris LG (1999) Potential impact of the introduced Asian shore crab, Hemigrapsus sanguineus, in northern New England: diet, feeding preferences, and overlap with the green crab, Carcinus maenas. In: Pedersen J (ed) Marine Bioinvasions: Proc 1st Natl Conf, Cambridge, MA, 24-27 January 1999. MIT Sea Grant College Program, Cambridge, MA, p 208-220

* Tyrrell MC, Guarino PA, Harris LG (2006) Predatory impacts of two introduced crab species: inferences from microcosms. Northeast Nat 13:375-390

Vitousek PM, D'Antonio CM, Loope LL, Rejmánek M, Westbrooks R (1997) Introduced species: a significant component of human-caused global change. NZ J Ecol 21:1-16

Williams AB, McDermott JJ (1990) An eastern United States record for the western Indo-Pacific crab, Hemigrapsus sanguineus (Crustacea: Decapoda: Grapsidae). Proc Biol Soc Wash 103:108-109

Yamaguchi T (2004) Seasonal changes in the energy content of females of the fiddler crab, Uca lactea, especially during the reproductive period. Crustaceana 76:1371-1397

Zeng Y, McLay C, Yeo DCJ (2014) Capital or income breeding crabs: Who are the better invaders? Crustaceana 87 : 1648-1656

Submitted: April 13, 2018; Accepted: July 24, 2018

Proofs received from author(s): August 19, 2018 